Jurnal Sasi Vol.16. No.3 Bulan Juli - September 2010

\title{
PRAKTEK ILLEGAL FISHING DI PERAIRAN MALUKU SEBAGAI BENTUK KEJAHATAN EKONOMI
}

\author{
Oleh: Yanti Amelia Lewerissa
}

\begin{abstract}
The potential of fisheries in the waters of Maluku is so large that it is often used by other affiliated companies both local and foreign fish for fishing illegally. Illegal fishing practices, and brought most of the catch to foreign countries without going through the formal examination procedure proved to be the impact of revenue losses for local or central government. The core issue in this study is whether the practice of illegal fishing in the waters of Maluku can categorize as economic crimes. Writing method used in this paper is a type of juridical normative deskritif analytical writing. The study concluded that the effect caused by the existence of this criminal act, then the state and the Government of the Republic of Indonesia suffered losses and has led to delays in national development. Therefore, it kriminologi, illegal fishing, the type of crime can be classified into economic crimes.
\end{abstract}

Keywords: Illegal Fishing, Economic Crime

\section{A. LATAR BELAKANG.}

Provinsi Maluku sebagai provinsi kepulauan, secara geografis memiliki luas $712.479,69 \mathrm{Km}^{2}$, dengan luas lautan sebesar $658.294,69 \mathrm{Km}^{2}$ atau $(92,4 \%)$ dan luas daratan $54.185 \mathrm{Km}^{2}$ atau $(7,6 \%)$. Luas daratan terdiri dari pulau-pulau besar dan kepulauan kecil, baik secara berkelompok maupun terpencil. Dengan luas lautan yang $(92,4 \%)$ tersebut, tersimpan potensi kekayaan alam berupa ikan, yang umumnya terdapat di sekitar Laut Seram, Laut Banda dan Laut Arafura, sehingga hasilnya dapat dimanfaatkan secara nasional sebesar $(26,3 \%)$ per tahunnya, di mana tergambar bahawa potensi perikanan nasional sebesar 6,26 juta ton/tahun, sedangkan potensi perikanan Provinsi Maluku adalah sebesar 1,64 juta ton/tahun atau $(26,3 \%)$ dari potensi nasional. ( Bubut W. Andibya et al, 2008 : 120).

Besarnya potensi perikanan di perairan Provinsi Maluku ini, menyebabkan kondisi demikian sering dimanfaatkan oleh perusahan-perusahan ikan dan nelayannelayan tradisionil untuk melakukan penangkapan ikan secara illegal. Dengan keadaan demikian, maka secara sosiokriminologis dapat diasumsikan beberapa bentuk illegal fishing secara variatif yang sering terjadi di perairan Maluku, seperti :

1. Transfer ikan tanpa izin;

2. Penggunaan dokumen palsu;

3. Penangkapan ikan dengan menggunakan jaring terlarang (pukat harimau);

4. Mengangkut jaring yang dilarang;

5. Pelanggaran aturan pelayaran berupa tidak dilengkapi dispensasi bendera kapal;

6. Tidak sahnya surat laut kapal, anak buah kapal (ABK) tidak di sijil dan pelanggaran kemudahan khusus keimigrasian serta tenaga kerja asing yang tidak memiliki izin kerja 
Yanti A. Lewerissa, Praktek Illegal Fishing

Jurnal Sasi Vol.16. No.3 Bulan Juli - September 2010

Laut Banda dan laut Arafura merupakan perairan yang sangat ramai dihadiri oleh kapal-kapal ikan, baik kapal ikan Indonesia (KII) maupun kapal ikan asing (KIA) yang melakukan penangkapan ikan. Sebagian besar kegiatan penangkapan ikan di perairan Banda dan Arafura dilakukan oleh perusahan-perusahan dengan menggunakan kapal ikan asing (KIA), sedangkan hanya sebagian kecil saja penangkapan yang dilakukan oleh perusahaan lokal KII (kapal Ikan Indonesia). Disamping faktor kalahnya penggunaan teknologi dalam kegiatan penangkapan, juga disebabkan sedikitnya jumlah armada kapal TNI-AL yang beroperasi di wilayah laut Maluku, sehingga banyak pelanggaran atau kejahatan di bidang perikanan yang tidak terdeteksi sehingga tidak sedikit kekayaan laut perairan Maluku yang di bawa ke luar negeri.

Departemen Kelautan dan Perikanan memperkirakan dari 7.000 ijin operasi penangkapan ikan, di perairan Indonesia $70 \%$ diantaranya terdiri dari kapal asing. Karena itu, perkiraan kerugian dapat mencapai $\mathrm{Rp}$. 16,6 trilyun per tahun, berupa kerugian akibat hilangnya fee, iuran ketrampilan tenaga kerja, iuran hasil penangkapan dan lost akibat subsidi BBM secara tidak langsung. ( Akhmad Fauzi, 2005 : 132-133)

Praktik perikanan IUU (Illegal, Unreported, Unregulated) di laut Arafura sudah berlangsung sejak tahun 1976. Angkaangka pencurian ikan di laut Arafura masih cukup tinggi. Studi tentang perikanan IUU di Arafura yang dilakukan oleh Pusat Riset Perikanan Tangkap (PRPT) DKP bekerja sama dengan FAO pada tahun 2007-2008 menunjukkan bahwa pada periode 2001-2005, sekitar 1, 258 juta ton ikan setiap tahun yang hilang karena praktek IUU. Jumlah ini terdiri dari 239,7 ribu ton ikan setiap tahun dibuang atau sering juga disebut by catch (hasil tangkapan sampingan). 364,4 ribu ton ikan hasil tangkapan yang tidak dilapor dan 654,6 ribu ton ikan hasil tangkapan yang ditangkap secara illegal. (Victor PH Nikijuluw, 2008 : 75)

Secara yuridis, illegal fishing dengan beberapa bentuk perbuatan yang sebagaimana telah disebutkan sebelumnya, dapat digolongkan sebagai tindak pidana perikanan sebagaimana termuat dalam Bab XV Ketentuan Pidana Undang-Undang Nomor 31 Tahun 2004 tentang Perikanan dengan kwalifikasi kejahatan pada beberapa pasal dan beberapa pasal lainnya adalah pelanggaran. Namun, jika dikaji dari tingkat dan besarnya kerugian negara yang dialami setiap tahunnya, maka sebagai perbuatan illegal, kejahatan ini sebenarnya dapat digolongkan sebagai kejahatan ekonomi (economic crime). ( Romli Atmasasmita, 1995 : 56)

Di dalam Crime and Justice Vol 2 tahun (1983 : 671), dirumuskan "economic crimes" sebagai "criminal activity with significant similarity to the economic activity of normal, non criminal business". Dalam kaitan itu, maka Edmind W. Witcth mengemukakan tiga karakteristik (features of economic crime) dari kejahatan ekonomi, yakni, pertama, pelaku menggunakan modus operandi yang sulit dibedakan dengan modus operandi kegiatan ekonomi pada umumnya. Kedua, tindak pidana ini biasanya melibatkan pengusaha-pengusaha yang sukses dalam bidangnya, dan Ketiga, tindak pidana memerlukan penanganan atau pengendalian secara khusus dari aparatur penegak hukum pada umumnya.

Dengan motif dan modus operandi, illegal fishing dapat digolongkan sebagai kejahatan ekonomi (economic crime). Hal ini sangat beralasan, sebab di dalam penjelasan umum Undang-Undang Nomor 31 Tahun 2004 tentang Perikanan, antara lain menegaskan bahwa :

Pengelolaan perikanan perlu dilakukan secara berhati-hati dengan berdasarkan asas manfaat, keadilan, kemitraan, pemerataan, keterpaduan, keterbukaan, efisiensi dan kelestarian yang berkelanjutan. Untuk 
menjamin terselenggaranya pengelolaan sumberdaya ikan secara optimal dan berkelanjutan perlu ditingkatkan peran pengawas perikanan menjadi sangat penting dan strategis dalam rangka menunjang pembangunan perikanan secara terkendali dan sesuai dengan asas pengelolaan perikanan, sehingga pembangunan dapat berjalan secara berkelanjutan.

Bertolak dari penjelasan sebagaimana dikemukakan di atas, maka inti permasalahan dalam penulisan ini adalah sebagai berikut : Apakah praktek illegal fishing di Perairan Maluku dapat dikategorikan sebagai kejahatan ekonomi?

\section{B. PEMBAHASAN}

Dari berbagai Kongres PBB yang membicarakan "Crime Ttrends and Crime Prevention Strategies", antara lain disimpulkan bahwa: (Barda Nawawi Arief, 2002: 9)

1. Pembangunan pada hakikatnya tidak bersifat kriminogen, khususnya apabila hasil-hasil pembangunan itu didistribusikan secara pantas dan adil kepada semua rakyat serta menunjang kemajuan seluruh kondisi sosial;

2. Pembangunan dapat besifat kriminogen atau meningkatkan kriminalitas, apabila pembangunan itu direncanakan secara tidak rasional, timpang atau tidk seimbang, menggabaikan nilai-nilai cultural dan moral serta tidak mencakup strategis perlindungan masyarakat yang intergral.

Beberapa perubahan bentuk dan dimensi kejahatan yang dibicarakan antara lain : (Barda Nawawi Arief, 2002 : 13)
1. "crime as business", termasuk dalam kejahatan ini seperti pecemaran lingkungan, perlindungan konsumen dan kejahatan perbankan, di samping organized crime, white colour crime dan korupsi.

2. Tindak pidana yang berhubungan dengan hasil-hasil pekerjaan seni dan kekeyaan budaya, objek-objek budaya dan warisan budaya;

3. Kejahatan yang berhubungan dengan alkohol dan penyalahgunaan obat-obatan.

4. Perbuatan kekerasan antar perorangan (interpersonal violence), teristimewa dikalangan remaja.

5. Perbuatan kekerasan yang bersfat transnasional dan internasional, yang disebut dengan perbuatan-perbuatan terorisme.

6. Kejahatan yang berhubungan dengan lalu lintas kendaraan bermotor.

7. Kejahatan yang berhubungan dengan perpindahan tempat (migrasi) dan pelarian pengungsi akibat bencana alam dan peperangan.

8. Kejahatan yang dilakukan oleh wanita.

Dari berbagai studi kejahatan dan pengaruhnya terhadap pembangunan, diakui bahwa the cost of crime mesti menjadi tanggungan pemerintah, dan karenanya berdampak pada timbulnya kerugian, seperti :

1. Kerugian-kerugian terhadap individu dan masyarakat.

2. Baya-biaya atau pengeluaran masyarakat untuk melakukan pencegahan dan pengendalian kejahatan; dan

3. Kegelisahan-kegelisahan yang timbul di masyarakat sehubungan dengan merata dan meningkatnya kejahatan-kejahatan kekerasan dan kejahatan terhadap harta benda.

Memperhatikan dampak negatif kejahatan ekonomi yang terjadi bekalangan ini, maka wajar jika perhatian mesti ditujukan pada bagaimana mencari upaya penanggulangan yang tepat dan rasional. Salah satunya adalah, penggunaan sarana 
hukum pidana. Selama ini orang masih saja mengakui bahwa hukum pidana, inklusif sanksi pidana masih dianggap ampuh. Pandangan demikian tidaklah keliru, sebab manfaatnya masih relevan dalam penyelenggaraan sistem peradilan pidana, walaupun dalam konteks tujuan yang hendak dicapai perlu dirasionalisasikan sesuai arah dan perkembangan hukum pidana ke depan.

Kejahatan ekonomi dapat dilihat secara sempit sebagai tindak pidana sebagaimana diatur dalam Undang-Undang Nomor : 7/Drt/Tahun 1955 tentang Pengusutan, Penuntutan dan Peradilan Tindak Pidana Ekonomi, yang selanjutnya disingkat Undang-Undang Tindak Pidana Ekonomi. Secara luas kejahatan ekonomi, merupakan semua tindak pidana di luar undang-undang tindak pidana ekonomi yang bercorak atau bermotifkan ekonomi atau yang dapat mempunyai pengaruh negatif terhadap perekonomian dan keuangan negara yang sehat. Kegiatan di bidang ini meliputi bidang yang sangat menonjol dalam bidang usaha perdagangan, industri dan perbankan. Oleh karena itu, ruang lingkup kejahatan ekonomi sangatlah luas. Ada yang mengelompokannya ke dalam tiga jenis pokok kejahatan ekonomi (three major types of economic crime), yaitu:

1. Property crimes, yaitu perbuatan-perbuatan yang mengancam keselamatan harta benda/kekayaan seseorang atau negara (acts that threaten property held by private persons or by the state);

2. Regulary crimes, yaitu perbuatanperbuatan yang melanggar aturan-aturan pemerintah (actions that violate governement regulations); dan

3. Tax crimes, yaitu pelanggaran mengenai pertanggungjawaban atau pelanggaran syarat-syarat yang berhubungan dengan pembuatan laporan menurut UU pajak (violations of the liability or reporting requirements of the tax laws). (Muladi dan Barda Nawawi Arief, 1992 : 156-157)
Selanjutnya dalam Pasal 1 UndangUndang Tindak Pidana Ekonomi, disebutkan bahwa yang disebut tindak pidana ekonomi ialah:

1e. Pelanggaran suatu ketentuan dalam atau berdasarkan (Garis bawahi oleh penulis):
a. "Ordonantie
Gecontroleerde Goederen 1948" (Staatsblad 1948 No. 144) sebagaimana diubah dan ditambah dengan Staatsblad 1949 No. 160;

b. Prijsbeheersing-ordonantie 1948" (Staatsblad 1948 No. 259);

c. "Undang-Undang Penimbunan Barang-barang 1951" (Lembaran Negara tahun 1953 No. 4);
d. "Rijsordonantie 1948" (Staatsblad 1948 No. 253);

e. "Undang-Undang Darurat kewajiban penggilingan padi" (Lembaran Negara tahun 1952 No. 33);

f. "Diviezen Ordonantie 1940" (Staatsblad 1940 No. 205).

2e. Tindak-tindak pidana tersebut dalam pasal-pasal 26, 32, dan 33 undang-undang darurat ini;

3e. Pelaksanaan suatu ketentuan dalam atau berdasar (Garis bawahi oleh penulis) undang-undang lain, sekedar undangundang itu menyebutkan pelanggaran itu sebagai tindak pidana ekonomi.

Dalam Pasal 32 UU TPE, dirumuskan bahwa tindak pidana ekonomi adalah "barangsiapa dengan sengaja berbuat atau tidak berbuat sesuatu yang bertentangan dengan suatu hukuman tambahan sebagaimana tercantum dalam pasal 7 ayat 1 sub a, b, atau e, dengan suatu tindakan tatatertib seperti yang tercantum dalam pasal 8 , dengan suatu peraturan seperti termaksud dalam pasal 10 atau dengan suatu tindakan tata-tertib sementara atau menghindari hukuman tambahan, tindakan tata-tertib, peraturan, tindakan tata-tertib sementara seperti tersebut di atas, maka ia melakukan suatu tindak pidana ekonomi. Selanjutnya 
Pasal 33 merumusakan Barangsiapa sengaja, baik sendiri maupun dengan perantara orang lain, menarik bagian-bagian kekayaan untuk dihindarkan dari tagihan-tagihan atau pelaksanaan suatu hukuman, tindakan tatatertib atau tindakan tata-tertib sementara yang dijatuhkan berdasarkan undang-undang darurat ini, maka ia melakukan suatu tindak pidana ekonomi.

Pengertian tindak pidana ekonomi lainnya sebagaimana diatur pada Pasal $1 \mathrm{sub}$ 3 e, yaitu pelanggaran suatu ketentuan dalam atau "berdasar" undang-undang lain, sekedar undang-undang itu menyebutkan pelanggaran itu sebagai tindak pidana ekonomi.

Terhadap rumusan demikian, Surprapto sebagaimana dikutip R. Wiyono, menegaskan bahwa ketentuan ini memberikan kemungkinan di kemudian hari karena, mengingat pelanggaran-pelanggaran atas ketentuan di undang-undang atau peraturan lain ke dalam golongan tindak pidana ekonomi di masa datang. (R. Wiyono, 1975:12)

Dengan adanya kata "berdasar" sebagaimana dalam pasal baik yang terdapat dalam Pasal 1 sub-1e maupun sub-3e, maka jelaslah bahwa pembentuk undang-undang dapat mendelegasikan kekuasaan dan kewenangan legislatif kepada pembuat peraturan perundang-undangan lain, baik yang sederajat maupun yang lebih rendah. Oleh sebab itu, untuk dapat memahami pengertian tindak pidana ekonomi, bukan hanya yang diatur dalam Pasal 1 sub-1 dan sub-3, melainkan dapat pula meliputi peraturan perundang-undangan lain yang mempunyai tujuan mengamankan dan mendukung usahausaha pemerintah guna meningkatkan kemakmuran rakyat di bidang ekonomi.

Menurut Anwar, ada 2 (dua) jenis kelompok tindak pidana di bidang ekonomi, yaitu (1) tindak pidana di bidang ekonomi dalam arti luas dan (2) tindak pidana di bidang ekonomi dalam arti sempit. Selanjutnya dijelaskan jenis tindak pidana di bidang ekonomi dalam arti sempit disebut tindak pidana ekonomi yang bersumber pada Pasal 1 Undang-Undang Tindak Pidana Ekonomi (Pasal 1 sub-1e, Pasal 1 sub-2e, dan Pasal 1 sub-3e). Sedangkan tindak pidana di bidang ekonomi dalam arti luas terdiri atas (a) perbuatan pelanggaran ketentuan dari peraturan-peraturan di bidang ekonomi, pelanggaran mana diancam dengan pidana yang tidak tercantum dalam Undang-Undang Tindak Pidana Ekonomi (peraturan khusus lainnya) dan (b) perbuatan-perbuatan pelanggaran hukum yang menyangkut bidang ekonomi yang dapat diberlakukan beberapa ketentuan dalam KUHP. (Anwar, $1986: 7-20$ )

Friedmann sebagaimana dikutip oleh Muladi dan Barda Nawawi Arief, mengemukakan, bahwa di dalam tindak pidana ekonomi terumus, the function of criminal law not only to protect private property against unlawful interference, but also to protect the basic economic order of the nation. Lebih lanjut dikemukakan, apabila digunakan pendekatan teknis, maka kejahatan ekonomi lebih menampakkan dirinya sebagai kejahatan di lingkungan bisnis yakni bilamana pengetahuan khusus tentang bisnis diperlukan untuk menilai kasus yang terjadi. Dalam hal ini batasan yang dapat dikemukakan adalah setiap perbuatan yang dilakukan oleh orang dan atau badan hukum, tanpa menggunakan kekerasan, bersifat melawan hukum, yang hakikatnya mengandung unsur-unsur penipuan, memberikan gambaran salah, penggelapan, manipulasi, melanggar kepercayaan, akal-akalan atau pengelakan peraturan (garis bawah penulis). Pendekatan sosial dapat digunakan apabila kita bermaksud untuk memberatkan kepada kepentingankepentingan negara dan masyarakat dalam artian bahwa perbuatan tersebut melanggar kepentingan negara dan masyarakat secara umum, tidak hanya kepentingan korban yang bersifat individual (orang atau perusahaan). Apabila ini yang kita lakukan, maka yang kita 
gunakan adalah istilah tindak pidana sosial ekonomi. Istilah ini saya kira tepat digunakan di Indonesia yang sedang giat-giatnya meningkatkan taraf hidup rakyat dalam kerangka melaksanakan tugas konstitusi yakni untuk memajukan kesejahteraan umum. (Muladi dan Barda Nawawi Arief, 1992 : 17)

Bertolak dari penjelasan terkahir di atas, maka tindak pidana ekonomi paling tidak mengandung unsur-unsur sebagai berikut : (Muladi dan Barda Nawawi Arief, 1992 : 20)

1. Perbuatan dilakukan dalam kerangka kegiatan ekonomis yang pada dasarnya bersifat normal dan sah.

2. Perbuatan tersebut melanggar atau merugikan kepentingan negara atau masyarakat secara umum, tidak hanya kepentingan individual.

3. Perbuatan itu mencakup pula perbuatan di lingkungan bisnis yang merugikan perusahaan lain atau individu lain.

Praktek illegal fishing yang merupakan tindak pidana perikanan sebagaimana dimaksud dalam UndangUndang Nomor 31 Tahun 2004 itu dapat dikategorikan sebagai bentuk dari kejahatan ekonomi. Beberapa alasan akademiknya, adalah bahwa perilaku illegal fishing oleh CCRF-FAO dikategorikan sebagai illegal, unreported and unregulated (IUU) Fishing. Itulah sebabnya dari data yang ditemukan, fenomena perbuatan illegal fishing meliputi :

a. Perbuatan melakukan penangkapan ikan dengan tidak memiliki dokumen Surat Izin Usaha Perikanan (SIUP), Surat Izin Penangkapan Ikan (SIPI);

b. Perbuatan melakukan pengakutan ikan dengan tidak memiliki dokumen Surat Izin Kapal Pengakut Ikan (SIKPI);

c. Perbuatan melakukan penangkapan ikan yang melanggar peraturan perundangundangan di bidang perikanan, diantaranya tidak melapor, penangkapan tidak pada lokasi penangkapan (fishing ground), penggunaan anak buah kapal (ABK) asing, dan lain-lain; d. Perbuatan melakukan penangkapan ikan dengan memiliki dokumen SIUP, SIPI, dan SIKPI palsu, dan asli tapi palsu;

e. Perbuatan melakukan transhipment di laut oleh kapal ikan asing yang tidak dalam satu perusahan; dan

f. Penangkapan ikan dengan menggunakan bahan/alat yang dapat merusak lingkungan laut.

Jika perbuatan tersebut dikaitkan dengan rumusan dari pasal-pasal dalam Undang-Undang Nomor 31 Tahun 2004 dimana telah mengalami beberapa perubahan berdasarkan Undang-Undang Nomor 45 Tahun 2009 tentang Perubahan Terhadap Undang-Undang Nomor 31 Tahun 2004 tentang Perikanan, maka praktek illegal fishing sebagaimana dimaksudkan ini dapat diklasifikasikan juga sebagai tindak pidana perikanan, karena :

1. Penangkapan ikan dilakukan dengan menggunakan bahan/alat dan cara yang membahayakan kelestarian sumberdaya ikan dan lingkungan laut (Tindak Pidana menurut Pasal 84 ayat (1), ayat (2), ayat (3));

2. Penangkapan ikan yang melanggar ketentuan perundang-undangan perikanan (Tindak Pidana menurut Pasal 85); ketentuan Pasal 85 telah diubah dalam Undang-Undang Nomor 45 Tahun 2009 tentang Perubahan Terhadap UndangUndang Nomor 31 Tahun 2004.

3. Penangkapan dan pengolahan ikan dengan tidak memiliki SIUP, SIPI, dan SIKPI (Tindak Pidana menurut Pasal 92, Pasal 93, dan Pasal 94); ketentuan Pasal 93 dan Pasal 94 mengalami perubahan berdasarkan Undang-Undang Nomor 45 Tahun 2009 tentang Perubahan Terhadap Undang-Undang Nomor 31 Tahun 2004.

4. Melakukan transhipment di laut (Tindak Pidana menurut Pasal 94). Mengalami perubahan.

Unsur pertama dari pasal-pasal sebagaimana dikemukakan di atas jelas 
menegaskan bahwa pelaku tindak pidana bukan saja individu sebagai subjek tindak pidana, tetapi juga korporasi atau badan hukum. Bahkan dalam Pasal 101 UndangUndang Nomor 31 Tahun 2004 secara tegas mengatur tindakan yang dilakukan oleh korporasi, berupa penjatuhan sanksi terhadap pengurusnya dan pidana dendanya ditambah 1/3 (sepertiga) dari pidana yang dijatuhkan. Sedangkan unsur perbuatan "melakukan penangkapan ikan dan/atau pembudidayaan ikan", Pasal 1 angka 5 menegaskan bahwa "penangkapan ikan adalah kegiatan untuk memperoleh ikan di perairan yang tidak dalam keadaan dibudidayakan dengan alat atau cara apapun, termasuk kegiatan yang menggunakan kapal untuk memuat, mengangkut, menyimpang, mendinginkan, menangani, mengolah, dan/atau mengawetkan". Termasuk di dalamnya pengertian pembudidayaan ikan sebagai kegiatan untuk memelihara, membesarkan, dan/atau membiakkan ikan serta memanen hasilnya dalam lingkungan yang terkontrol, termasuk kegiatan yang menggunakan kapal untuk memuat, mengangkut, menyimpan, mendinginkan, menangani, mengolah, dan/atau mengawetkannya. (Pasal 1 butir 6)

Terhadap unsur "penggunaan alat penangkapan ikan dan alat bantu penangkapan ikan", Pasal 7 ayat (1) huruf e dan f beserta penjelasannya menegaskan, bahwa "ukuran alat penangkapan", termasuk juga ukuran mata jaring, dan "alat bantu penangkapan" merupakan sarana, perlengkapan, atau benda lain yang dipergunakan untuk membantu dalam rangka efisiensi dan efektivitas penangkapan ikan, seperti lampu, rumpon, dan terumbu karang buatan. Sedangkan terhadap unsur "yang tidak memiliki SIUP, SIPI, dan SIKPI", maka kualifikasi perbuatannya lebih ditujukan pada perbuatan yang tidak sesuai dengan kewajiban dalam melakukan usaha perikanan sebagaimana diatur dalam Pasal 26 ayat (1), Pasal 27 ayat (1) mengalami perubahan berdasarkan
Undang-Undang Nomor 45 Tahun 2009 dan Pasal 28 ayat (1).

Dari uraian unsur-unsur rumusan tindak pidana di atas, disimpulkan bahwa praktek illegal fishing dapat digolong sebagai tindak pidana di bidang perikanan, namun dilihat dari akibat yang ditimbulkan, negara dan Pemerintah Republik Indonesia mengalami kerugian dan berakibat terhadap terhambatnya pembangunan nasional. Karena itu dapat digolongkan sebagai kejahatan ekonomi. Pengangkutan ikan secara illegal dan Unreported secara langsung dari peraian Indonesia ke luar negeri memiliki dampak ekonomi yang besar. Kerugian yang ditimbulkan dapat berupa ;

a. Pengangkutan ikan secara illegal dan Unreported akan mengurangi kemampuan Indonesia untuk mencatat jumlah sebetulnya produksi ikan di perairan Indonesia. Data riil ini sangat penting, karena dapat menjadi basis estimasi potensi dan tingkat pemanfaatan sumber daya perikanan di perairan Indonesia, dan selanjutnya dapat dihitung untuk menentukan potensi serta kebutuhan investasi.

b. Pengangkutan ikan secara illegal dan Unreported mengakibatkan industri pengolahan perikanan di daratan Indonesia mengalami kekurangan suplai bahan baku. Oleh karena itu industry ini menjadi underutilize. Banyak pabrik yang tutup, muncul pengangguran, serta industry penunjang ikut kehilangan mitra dan langganannya.

c. Pengangkutan ikan secara illegal dan Unreported membuat kekuatan ekspor produksi perikanan Indonesia menjadi semakin melemah, pengembangan produksi sangat terbatas dan nilai ekspor tidak bertambah secara signifikan. Disaat yang sama, ikan yang tersedia bagi konsumen dalam negeri menjadi sangat terbatas. 


\section{PENUTUP}

Kejahatan ekonomi sebagai kejahatan yang memiliki dimensi, ruang lingkup dan dampak yang sangat luas dan melampaui batas-batas teritorial. Praktek illegal fishing merupakan tindak pidana di bidang perikanan yang dikategorikan sebagai kejahatan diatur dalam Pasal 84, Pasal 85, Pasal 92, Pasal 93, dan Pasal 94 Undang-Undang Nomor 31 Tahun 2004. Akibat yang ditimbulkan dengan adanya tindak pidana ini, maka negara dan Pemerintah Republik Indonesia mengalami kerugian serta berakibat terhadap terhambatnya pembangunan nasional. Oleh karena itu, secara kriminologik, tipe kejahatan illegal fishing dapat digolongkan ke dalam kejahatan ekonomi (economic crime). Rrumusan tindak pidana di bidang perikanan memiliki faktor kriminogen yang serupa dengan tindak pidana ekonomi dan akibat yang ditimbulkan berdampak pada kepentingan bangsa dan negara dalam mencapai kemakmuran rakyat.

\section{DAFTAR PUSTAKA}

Anwar, HAK Moch, Hukum Pidana Di Bidang Ekonomi, Alumni, Bandung, 1986.

Atmasasmita, Romli, Kapita Selekta Hukum Pidana dan Kriminologi, Mandar Maju, Bandung. 1995.

Barda Nawawi Arief, Bunga Rampai Kebijakan Hukum Pidana, Penerbit PT. Citra Aditya Bakti, Semarang. 2002.

Bubut W. Andibya.. et al, Maluku The Wonderful Island, Gibion Group Publicastion, Jakarta, 2008.

Fauzi, Akhmad, Kebijakan Perikanan dan Kelautan, Isu, Sintesis, dan Gagasan, Penerbit PT Gramedia Pustaka Utama, Jakarta, 2005.

Muladi dan Barda Nawawi Arief, Bunga Rampai Hukum Pidana, Penerbit Alumni, Bandung, 1992.

Muladi dan Barda Nawawi Arief, Teori-Teori dan Kebijakan Pidana, Edisi Revisi, Alumni, Bandung, 2005.

Wiyono, R., Pengantar Tindak Pidana Ekonomi Indonesia, Alumni, Bandung, 1975.

Victor PH Nikijuluw, Blue Water Crime, Pustaka Cidesindo, Jakarta, 2008. 